\title{
Scholarly Activity of Polish Researchers in Humanities in Kiev, Kharkov and Novorossiya Imperial Universities
}

\section{A. Yu. Bazhenova}

For citation: Bazhenova A. Yu. Scholarly Activity of Polish Researchers in Humanities in Kiev, Kharkov and Novorossiya Imperial Universities. Vestnik of Saint Petersburg University. History, 2019, vol. 64, issue 1, pp. 70-91. https://doi.org/10.21638/11701/spbu02.2019.104

The subject of this paper is the study of the scholarly activity of Polish researchers in humanities - philologists, historians, philosophers, literary critics and jurists - who worked at the universities in Kiev, Kharkov, and Odessa in the second half of the $19^{\text {th }}$ and early $20^{\text {th }}$ centuries. Covered in this article are: Henryk Jakubakis, Władysław Jurgiewicz, Witold Klinger, Leonard Kołmaczewski, Edmund Liwski, Witold Nowodworski, Józef Piechowski, Leon Szepielewicz, Alfons Walicki, Leopold Wojewódzki (Faculties of History and Philology), Konrad Dynowski, Leon Fiedorowicz, Alekander Mickiewicz, Jan Sobestyjański, Antoni Stanisławski, Eugeniusz Waśkowski (Faculties of Law). This article analyses the academic careers of the professors and determines the duration of their work at the aforementioned universities. It gives an overview of their contribution to the development of humanities and jurisprudence in Russia, and to the creation of academic schools in the field of humanities. The most significant group of Polish scholars became the specialists in classical philology (five professors). To some extent, a study of the distant historical epochs can be explained by the desire to disengage from the actual political situation in the country and from assessment of the developments of the recent past. Two academics represented each of the following disciplines: Western European literature, world history, and Roman law. The encyclopaedia of law, the history of Russian law, civil law and civil procedure, political economy and statistics were represented by a different Polish academic each. Some professors were also engaged in translations. This article is a step towards further study of the participation of Polish academics in the scholarly life of the Russian Empire.

Keywords: St. Vladimir University, Kharkov University, Novorossiya University, humanities, researcher, Polish, academic school.

\section{Научная деятельность польских ученых-гуманитариев в Киевском, Харьковском и Новороссийском императорских университетах}

\section{А.Ю. Баженова}

Для цитирования: Bazhenova A. Yu. Scholarly Activity of Polish Researchers in Humanities in Kiev, Kharkov and Novorossiya Imperial Universities // Вестник Санкт-Петербургского университета. История. 2019. Т. 64. Вып. 1. С. 70-91. https://doi.org/10.21638/11701/spbu02.2019.104

Anna Yu. Bazhenova - PhD in History, Research Fellow, Institute of East-Central Europe, ul. Niecala, 5, Lublin, 20-080, Poland; bagenova_a@inbox.ru

Анна Юрьевна Баженова - канд. ист. наук, науч. сотр., Институт Центрально-Восточной Европы, Польша, 20-080, Люблин, ул. Нецала, 5; bagenova_a@inbox.ru

(C) Санкт-Петербургский государственный университет, 2019 
В статье впервые в историографии комплексно исследуется научная деятельность польских ученых-гуманитариев: филологов, историков, философов, литературоведов, правоведов, работавших в университетах Киева, Харькова и Одессы во второй половине XIX - начале XX в. Среди них были Альфонс Валицкий, Леопольд Воеводский, Витольд Клингер, Леонард Колмачевский, Эдмунд Ливский, Витольд Новодворский, Осип Пеховский, Лев Шепелевич, Владислав Юргевич, Генрих Якубанис (историкофилологические факультеты), Евгений Васьковский, Конрад Дыновский, Александр Мицкевич, Иван Собестьянский, Антон Станиславский, Лев Федорович (юридические факультеты). Анализируются траектории академических карьер преподавателей и устанавливается продолжительность их работы в упомянутых учебных заведениях. Охарактеризован вклад польских исследователей в российскую науку, а также в создание и развитие гуманитарных университетских научных школ. Самую значительную группу преподавателей составляли специалисты по классической филологии (пять профессоров). В основном они концентрировались на тематике Древней Греции, изучая древнегреческую поэзию, историю, историографию, фольклор, мифологию и нравственность. Обращение ученых к отдаленным историческим эпохам можно объяснить желанием дистанцироваться от острой политической ситуации в стране и от оценок событий недавнего прошлого. Следующие по численности группы (по два преподавателя в каждой) состояли из специалистов по западноевропейской литературе, всеобщей истории и римскому праву. По одному человеку представляло разные области юриспруденции, а именно: энциклопедию права, историю русского права, гражданское право и гражданское судопроизводство, политическую экономию и статистику. Параллельно с исследованиями по предмету своей специализации некоторые преподаватели занимались также переводами с греческого, немецкого, итальянского, французского, английского, шведского языков как на русский, так и на польский языки. Публикация переводных сочинений значительно обогатила российскую и польскую науку и способствовала популяризации известных произведений зарубежных поэтов, философов и ученых. Исследование, представленное в статье, является шагом к дальнейшему изучению участия польских ученых в научной жизни Российской империи.

Ключевые слова: университет Св. Владимира, Харьковский университет, Новороссийский университет, ученый-гуманитарий, преподаватель, поляк, научная школа.

Kiev, Kharkov and Novorossiya universities played a significant role in the Russian system of higher education. Along with St. Petersburg, Moscow, Dorpat, Kazan and other universities, they attracted many students and academics of Polish origin. The article focuses on the scholarly activity of Polish researchers in humanities: philologists, historians, philosophers, literary critics and jurists who lectured at Kiev, Kharkov, and Novorossiya universities in the second half of the $19^{\text {th }}$ and early $20^{\text {th }}$ centuries. The paper gives an overview of their academic careers and scholarly activities during their work at these educational institutions. It analyses the contribution of Polish researchers in humanities to the development of humanities and jurisprudence in Russia, and to the creation of academic schools in the field of humanities.

In recent decades, the achievements of Poles at Kiev, Kharkov, and Novorossiya universities have been studied by Russian, Polish and Ukrainian historians. Among the first was a monograph by Jan Tabis about Poles at the University of St. Vladimir in 1834-1863 ${ }^{1}$. The author concentrated mainly on the socio-political activities of students and paid relatively little attention to the scientific achievements of Poles in Kiev. Artur Kijas published a number of important studies, which examined in detail the work of professors of Polish

1 Tabis J. Polacy na Uniwersytecie Kijowskim, 1834-1863. Kraków, 1974. 
origin at Kharkov University in 1805-1917². Oleg D'omin ${ }^{3}$, Konstantin Vasil'ev ${ }^{4}$ and Viacheslav Kuznetsov ${ }^{5}$, in their turn, focused on Polish professors at Novorossiya University.

Of particular interest in this article are the publications that study in a comprehensive way the activities of Poles in all the three universities. Among these researches is Jerzy Róziewicz's monograph on Russian-Polish academic relations in 1725-1918 ${ }^{6}$. To the author's credit, he worked out the criteria for counting Poles in the higher education institutions of the Russian Empire. Róziewicz also made a list of these professors and lecturers and presented their academic careers. He defined the following criteria for determining Polish identity: religion, geography, onomastics, as well as the existence of links with Poland and Polish culture. The scope of his research did not include those who descended from Polish-Russian families or whose grandparents were Polish. In the early

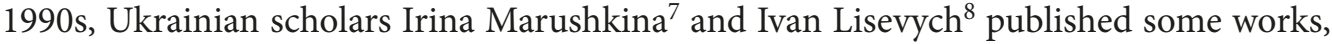
which only briefly examined the activity of Poles at Kiev, Kharkov and Novorossiya universities in the second half of the $19^{\text {th }}$ and early $20^{\text {th }}$ century. However, these studies have not been further developed during the following decades. The overwhelming majority of publications have explored the life and activities of individual Polish professors, above all, the most outstanding of them. Thus, despite a relatively large number of works, the professional activities of Polish researchers in humanities at aforementioned universities have not become a subject of a detailed study of them as a separate group yet.

\section{Polish academics at Kiev, Kharkov and Novorossiya universities}

The history of the University of St. Vladimir in Kiev is closely linked to the fate of Polish people. The university was founded by the decree of Nicholas I on November 8, 1833 after Kremenets Lyceum and Vilna University had been closed following the Polish Uprising of 1830/31. Many Polish academics moved to the new university: seventeen from Kremenets and two from Vilna 9 . However, after a couple of years almost all of them were either transferred to other educational institutions, or fired. The discovery of the secret

2 Kijas A.: 1) Polacy na Uniwersytecie Charkowskim 1805-1917. Wydanie drugie poprawione i uzupełnione. Poznań, 2008; 2) Polscy profesorowie na Uniwersytecie Charkowskim do 1917 roku // Wrocławskie Studia Wschodnie. 2011. No. 15. P.47-64.

3 D’omin O. Pol's'ka profesura Novorosiis'koho universytetu (1865-1920 rr.) // Poliaky na Pivdni Ukrainy = Polacy na Południowej Ukrainie / science eds T. Tsysel's'kyi, V.H. Kushnir. Odessa [et al.], 2006. P. 157-159.

4 Vasil'ev K. Poliaki v Odesse: vrachi i farmatsevty (do 1920 g.) // Ibid. P. 111-123.

${ }^{5}$ Kuznetsov V.O. Vnesok pol's'koi intelihentsii u rozvytok mikrobiolohichnoi naukovoi shkoly $\mathrm{v}$ Odes'komu (Novorosiis'komu) universyteti imeni I. I. Mechnykova // Poliaky na Pivdni Ukrainy ta v Kry$\mathrm{mu}=$ Polacy na Południowej Ukrainie i Krzymie / eds T. Tsysel's'kyi, E. Chapevs'kyi, V. Kushnir. Odessa [et al.], 2007. P. 264-276.

6 Róziewicz J. Polsko-rosyjskie powiązania naukowe (1725-1918). Wrocław [et al.], 1984.

7 Marushkina I.M. Nauchno-prepodavatel'skaia deiatel'nost' pol'skikh uchenykh v universitetakh Ukrainy (konets XIX - nachalo XX v.) // Kul'turnye i obshchestvennye sviazi Ukrainy so stranami Evropy. Kiev, 1990. P. 195-211.

8 Lisevych I.T. U zatinku dvohlavoho orla (pol's'ka natsional'na menshyna na Nadniprians'kii Ukraini v druhii polovyni XIX — na pochatku XX st.). Kiev, 1993.

9 Poles constituted $36 \%$ of the university professors and instructors before 1839 . - Martseniuk R. Poliaky v Universyteti sv. Volodymyra (1834-1839): problemy kul'turnoi adaptatsii // Acta PolonoRuthenica. 2011. No. 16. P. 91. 
organization of Polish patriots among university students in 1839 (the case of Szymon Konarski) became the reason for dismissing the Polish professors ${ }^{10}$.

It is worth mentioning that the University of St. Vladimir had always been under the special control of the Russian government in view of its territorial and historical ties with Poland. The political situation in the Kingdom of Poland and Polish Insurrection of $1863 / 64$ prompted a response by the Russian government in relation to universities. A series of decrees and orders, which prevented the Poles from working at higher education institutions, were made. On September 27, 1868 a new order was issued about not appointing Roman Catholic persons of Polish origin native to the Kingdom of Poland and the western provinces to positions in educational institutions of the Ministry of Public Education. However, this ruling did not apply to Warsaw and Dorpat educational districts ${ }^{11}$.

The restrictions on the acceptance of Polish researchers to the University of St. Vladimir were finally lifted during the revolution of 1905-1907. As a result, three Poles (Jakubanis, Klinger, Nowodworski) were allowed as instructors at the Faculty of History and Philology in 1908. However, each new appointment would meet a resistance. It is important to mention here the case of a graduate of this university, philologist Witold Klinger. In 1912, he became an Associate Professor of the Department of Classical Philology. However, the conservative Kiev press launched a campaign against the scholar. As a sign of protest against the unjustified harassment, Klinger refused to hold the office and sent a letter to the Ministry of Public Education denouncing the practice of oppression of Polish cadres at the university. Only in 1917, Klinger achieved the position of the Professor of the Department of Classical Philology at Kiev University ${ }^{12}$.

The analysis of the distribution of academics of Polish origin throughout the faculties of Kiev and Kharkov universities in the second half of the $19^{\text {th }}$ and early $20^{\text {th }}$ century enables to conclude that most of them worked at the faculties of Medicine. The peculiarity of Novorossiya University was the concentration of Poles at the Faculty of Physics and Mathematics, mainly at the Division of Natural Sciences. This was due to the fact that the Faculty of Medicine was founded there only in 1900. There were significantly fewer academics at the faculties of History and Philology, as well as at the faculties of Law. That can be explained by the unwillingness of Russian government to give the Poles access to these spheres of education. The number of identified Polish academics is sixteen. Only three of them worked at the Faculty of History and Philology at the University of St. Vladimir in Kiev over the period of study (Henryk Jakubakis, Witold Klinger, Witold Nowodworski); and there was not a single one at the Faculty of Law. In Kharkov, six Poles lectured at the Faculty of History and Philology (Władysław Jurgiewicz, Leonard Kołmaczewski, Edmund Liwski, Józef Piechowski, Leon Szepielewicz, Alfons Walicki), and the other three at the Faculty of Law (Alekander Mickiewicz, Jan Sobestyjański, Antoni Stanisławski). At the same time in Odessa: two Poles worked at the Faculty of History and Philology (Władysław Jurgiewicz, Leopold Wojewódzki) and three ones worked at Law (Konrad Dynowski, Leon Fiedorowicz, Eugeniusz Waśkowski). Seven of them were graduates of

10 Marushkina I. M. Nauchno-prepodavatel'skaia deiatel'nost' pol'skikh uchenykh v universitetakh Ukrainy... P. 195.

11 Lisevych I.T. U zatinku dvohlavoho orla... P. 42-43.

12 Ibid. P. 47; Marushkina I. M. Nauchno-prepodavatel'skaia deiatel'nost' pol'skikh uchenykh v universitetakh Ukrainy... P. 198-199. 
Kiev (Dynowski, Jakubakis, Klinger), Kharkov (Liwski, Sobestyjański), and Novorossiya (Szepielewicz, Waśkowski) universities.

\section{Classical Philology and Philosophy}

Specialists in classical philology formed a significant group of Polish professors. Alfons Walicki (1806(8?)-1858) was one of the most famous professors of Kharkov University. He worked at the Department of Greek Literature and Antiquities from 1835-1858. In 1837, he became a Full Professor ${ }^{13}$ and served as a Dean of the first division of the Faculty of Philosophy (1841-1845). Walicki was a talented speaker and an outstanding connoisseur of classical antiquities. In 1832, he published a thesis on the Roman historian Cornelius Nepos ("De Cornelio Nepote". Dorpat, 1832), written in fine Latin. The author established the years of Nepos's life, presented his biography and re-established the content and sequence of individual parts of Nepos's work "On Famous Men". The study proved that Nepos lived and wrote in the $1^{\text {st }}$ century BC.

Walicki was not only a distinguished scholar, but also a translator of German, Swedish, English, and Greek literature into Polish, in addition to being a poet. He produced the first translation of Goethe's "Faust" into Polish (Wilno, 1844; the second part remained in manuscript) ${ }^{14}$ and of "Frithiof's Saga", created by Swedish writer Esaias Tegnér (Part 1, Warszawa, 1841/42; Part 2 remained in manuscript). Walicki also translated ancient authors. In particular, he published "Edyp Król” by Sophocles (Wilno, 1845), Xenophon's "Cyropedia" with comments in Russian, and a Greek dictionary (Charków, 1848). According to Szepielewicz, the translations of "Faust" and "Edyp Król" were made accurately, in full, and reproduced the metre of the originals. Walicki published relatively few books. Most of his works remained in manuscripts, and only a part of them survived. Among them are "Hipolit" ("Hippolytus") and "Medea" by Euripides, "Antygona" ("Antigone") by Sophocles, "Eumenidy" ("The Eumenides") by Aeschylus, Goethe's "Goetz von Berlichingen z żelazną ręką". The professor from Kharkov also wrote tragedy "Zbigniew: tragedia w pięciu aktach", which remained unpublished. The first part of it is preserved in the collection of the National Library in Warsaw ${ }^{15}$.

Walicki was a highly erudite scholar. His contemporaries remembered the following story. In 1839, an Ambassador of France, a famous researcher and writer Baron Prosper de Barante, passed through Kharkov. Looking at the university, he expressed a desire to listen to the lecture in a language he understood. The rector advised him to attend Walicki's lecture, however, nobody warned the professor about this visit. When Walicki saw Baron de Barante, he instantly changed the subject of the lecture and began to speak in

13 In this article, the author uses modern equivalents of the prerevolutionary posts: the full professor (Ordinarius), the associate professor (Extraordinarius), the assistant professor (Dozent), and the instructor (Privatdozent).

14 An earlier translation of Faust's fragment was published in 1826 (translator - Julian Korsak).

15 Błaszczyk G. Pierwsi Polacy na Uniwersytecie Dorpackim w latach 1802-1832 // Kwartalnik Historii Nauki i Techniki. 2007. R. 52. No.3-4. P.219; Rys dziejów literatury polskiej, podług notat A.Zdanowicza oraz innych źródeł / opracował i do ostatnich czasów doprowadził L. Sowiński. T.IV. Wilno, 1877. P. 146; Orgelbrand S. Encyklopedyja powszechna. T. XXVI. Uła - Wikaryusz. Warszawa, 1867. P. 340; Maslov M. A. Valitskii Al'fons Osipovich // Istoriko-filologicheskii fakul'tet Khar'kovskogo universiteta za pervye 100 let ego sushchestvovaniia (1805-1905) / eds M. G. Khalanskii, D. I. Bagalei. Kharkov, 1908. P. 175-183; Kijas A. Polacy na Uniwersytecie... P. 74-75. 
Latin about the contribution of French scholars to the study of classical antiquities. A noble guest was fascinated by the brilliant improvisation. A Russian literary critic Vissarion Belinsky, after visiting Kharkov University in 1840-ies, named Walicki "a star of the highest magnitude"16.

Józef Piechowski (1815-1891) was an acting Assistant Professor (since 1849), Associate Professor (1854), acting Full Professor (1859) and Full Professor (1868) at the Department of Greek Literature of Moscow University. A year later, he retired after 25 years of service and moved to Kharkov. He became an invited lecturer (1870), and later a Full Professor (1871-1885) at the Department of Greek Literature at Kharkov University. Master's and doctoral theses were the most important works by Piechowski ${ }^{17}$. He defended them in 1854 and 1868 respectively. Both studies were written in Latin, which the author was fluent in ${ }^{18}$. His master's thesis examined "The Art of Poetry" ("Epistle to the Pisos") ${ }^{19}$, a poem written by Horace. It is important to note that for more than two years Piechowski had worked exclusively on the Horace's text, and only after that he began to compare his conclusions with the opinions of other scholars. He determined a tripartite structure of Horace's poetics that was also supported by other researchers. The main concept was that the work of Horace is a complete poetics dedicated to all poetry as a whole, inasmuch as the writer touches upon various kinds of poetry ${ }^{20}$.

The second major Piechowski's study was his doctoral thesis "De ironia Iliadis"21. The author's goal was to collect the examples of irony in the "Iliad", and unexpectedly he found quite a lot of them, especially in the descriptions of various battles. This led Piechowski to suppose that Homer treated the main idea of his poem with irony as well. The scholar confirmed this assumption during a detailed research of the main conflict of the "Iliad". This, in turn, helped the scholar to explain many unclear details in the structure of the poem and to prove its unity without external criteria ${ }^{22}$. By using this new internal criterion the Piechowski's work became a pioneering one.

Władysław Jurgiewicz (1818-1898) was an expert on the history of ancient Rome and antiquities of the Northern Black Sea region. He served as an acting Assistant Professor (since 1844) and Assistant Professor (since 1847) at the Department of Greek and Roman Literature of Kharkov University. In 1858, Jurgiewicz was transferred to the Richelieu Lyceum in Odessa as a Professor of Roman literature. After the transformation of the lyceum into Novorossiya University in 1865, he became an Associate Professor, later Full Professor (1866-1872, 1882-1887) of Roman literature and the Dean of the Faculty of History and Philology (1868-1871). During 1877-1882, he continued as an invited lec-

${ }^{16}$ De-Pule M. Khar'kovskii universitet i D. I. Kachenovskii // Vestnik Evropy. 1874. No. I. P.93-96.

17 The master's thesis of that time corresponds to the current $\mathrm{PhD}$ thesis.

18 Derevitskii A. O.I. Pekhovskii (nekrolog) // Filologicheskoe obozrenie. 1891. Vol.1. P.213-214; Netushil I. V. Pekhovskii Osip Ivanovich // Istoriko-filologicheskii fakul'tet Khar'kovskogo universiteta za pervye 100 let ego sushchestvovaniia (1805-1905) / eds M. G. Khalanskii, D. I. Bagalei. Kharkov, 1908. P. 201-202.

19 Piechowski J. De Q. Horatii Flacci Epistola ad Pisones. Mosquae, 1853.

20 Netushil I. Osip Ivanovich Pekhovskii. Obozrenie ego ucheno-literaturnoi deiatel'nosti i biograficheskie dannye. Kharkov, 1902, P.7-9.

${ }^{21}$ Piechowski J. De ironia Iliadis. Mosquae, 1856.

22 Piechowski J. Sylwetki filologów klasycznych w Polsce: Józef Piechowski 1815-1891 // Meander. 1853. R. IX. No. 3. P. 143. 
turer. Jurgiewicz was a member, secretary (1875-1883) and a vice-president (1883-1898) of the Odessa Society of History and Antiquities ${ }^{23}$.

The main works by Jurgiewicz were his master's and doctoral theses: "De mundiciis veterum Graecorum et Romanorum” (1847), "De Jovis Lycaei natura cognominisque huius ratione" (1866), as well as an article "O pozharakh i predokhranitelnykh protiv nikh merakh v drevnem Rime” (1854) ${ }^{24}$. Immediately after moving to Odessa, he began to study the ancient Greek colonies on the Black Sea coast and medieval Italian settlements in Crimea. His research interests included epigraphy, numismatics, sigillography, history, and archaeology. Jurgiewicz examined epigraphic monuments of Olbia, Chersonese, Tire, and Panticapaeum. After analysing Greek inscriptions, he wrote a study on the pagan names mentioned in these inscriptions ("O mnimykh normandskikh imenakh v russkoi istorii". Odessa, 1866). His works on the stamps on the handles of amphorae from the ancient centres of the Northern Black Sea region deserve a separate mention ${ }^{25}$.

Thanks to Jurgiewicz, a school of medieval Italian epigraphy was formed at Novorossiya University. By analysing the texts of inscriptions from the Genoese cities of Crimea, he established when the fortifications of Soldaia (Sudak), Kaffa (Theodosia), and Cembalo (Balaklava) were built, and when Genoa affirmed its authority in Crimea. Jurgiewicz was the first to publish, prior to his Italian colleagues, the "Statute" of the Genoese colonies of 1449 in Latin and Russian. He also determined the specific functioning of remote Genoese colonies during the period of the decline of the power of Genoese republic in the Black Sea region ${ }^{26}$. In addition, the scholar initiated the research in medieval numismatics at the university. Jurgiewicz was one of the first explorers of Kaffa's coinage ("O monetakh genuėzskikh nakhodimykh v Rossii”. Odessa, 1870). He also participated in the organization of the restoration of monuments of antiquity, in particular, the tower of Constantine in Theodosia and the buildings of Sudak fortress ${ }^{27}$.

Leopold Wojewódzki (1846-1901) was an outstanding specialist in ancient history and philology, a researcher who devoted most of his life to the study of ancient mythology. He was an Assistant (1875-1882) and Full Professor of classical philology (1882-1899), a secretary of the Faculty of History and Philology $(1874-1876,1882-1884)$ at Novorossiya University. In 1899, because of the severe consequences of pulmonary tuberculosis, he was forced to stop lecturing and resigned ${ }^{28}$.

Wojewódzki's research interests included German literature (works of Heinrich Heine and other lyric writers), the history of antiquity, ancient Greek and Russian philology. He focused on simplifying Russian orthography, and was also interested in mathematics. However, the main field of his studies was ancient ethics and ancient Greek mythology ${ }^{29}$.

23 V. N. Iurgevich [nekrolog] // Istoricheskii vestnik. 1899. Vol. LXXV. P.367-369; V. R. V. N. Iurgevich (nekrolog) // Zhurnal Ministerstva narodnogo prosveshcheniia (further — ZhMNP). 1899. Ianvar'. P. 81-82.

24 V.R. V. N. Iurgevich (nekrolog). P. 82.

25 Shamanaev A. V. Vklad V. N. Iurgevicha v izuchenie i sokhranenie pamiatnikov Kryma // Antichnaia drevnost' i srednie veka. 2011. Iss. 40. P. 411-412.

26 [D'omin O.B.] Evoliutsiia istorychnoi nauky // Odes'kyi natsional'nyi universytet imeni I. I. Mechnykova. Istoriia ta suchasnist' (1865-2015) / ed. by I. M. Koval'. Odessa, 2015. P. 139.

27 Ibid. P. 141; Shamanaev A. V. Vklad V. N. Iurgevicha v izuchenie i sokhranenie pamiatnikov Kryma. P. 415, 419 .

28 Berezin S. Ie. Novi materialy do biohrafii L. F. Voievods'koho // Zapysky istorychnoho fakul'tetu. 2016. Iss. 27. P. 468.

29 Berezin S.Ie., Izbash T.O. Voievods'kyi Leopol'd Frantsevych // Profesory Odes'koho (Novorosiis'koho) universytetu. Biohrafichnyi slovnyk. T.2. Odessa, 2000. P. 234. 
In the master's thesis "Kannibalizm v grecheskikh mifakh: opyt po istorii razvitiia nravstvennosti" ${ }^{30}$ Wojewódzki attempted to prove that the myth is not so much a poetic creation as a source for the history of ancient ethics and morality. Consequently, the researcher's task is to find the original core of the myth, to determine the epoch to which it corresponds, and to identify the later additions. Wojewódzki was one of the first to show that ancient myths were a kind of collection of ethical norms and rules, religious and scientific ideas. The scholar tried to dispel the existing "idealization" of everyday life and moral notions in ancient Greek society. He thought that it was enough to prove the existence of cannibalism among ancient Greeks, so everyone would believe that other wild, immoral features were common to Greeks as well as to other peoples. Despite the controversy of some of the conclusions, the author's achievement was that he showed the stadiality of the Greek society, which went through the same phases of development as those of other peoples ${ }^{31}$.

The innovative views of Wojewódzki drew sharp criticism. At the same time, the important methodological significance of his work was recognized. The author used methods of anthropology, ethnography, comparative linguistics, which helped him to depart from the traditional way of exploring the history of Greek people. However, the general critical evaluation of the publication was negative, therefore since then the scholar had studied mainly the essence and content of the myths ${ }^{32}$.

In his doctoral thesis "Vvedenie v mifologiiu Odissei"33 Wojewódzki attempted to reduce the entire Homer's epos to the solar-lunar-stellar myth. In his opinion, "The Odyssey" was based on different versions of a single myth about the relation of the sun to the stars $^{34}$. According to Wojewódzki's theory, the male characters of "The Odyssey" were the reflections of the sun, and their names were derived from different names and epithets of the solar deity. Female characters were representatives of the moon. Friends and enemies of the sun (Odysseus) were the stars that related to the protagonist as household members and servants, or guards and soldiers ${ }^{35}$. This research caused even a greater storm of criticism than the master's thesis.

Witold Klinger (1875-1962) was a classical philologist, ethnographer, translator and the founder of the so-called Poznan philological school. He was an Instructor at the University of St. Vladimir since 1908. From the next year onward, the scholar lectured at the Higher Women's Courses in Kiev. In 1915, he agreed to chair the Department of Classical Philology at Nezhin Prince Bezborodko Historical-Philological Institute, while retaining the position of an Instructor at the university. Klinger became a Professor at Kiev University only in 1917. In addition, he lectured at the Polish University Collegium and at one of the Polish gymnasiums in Kiev (1918), and chaired the Ethnographic Commission at the Ukrainian Academy of Sciences. In 1920, the scholar moved to Poland, where he chaired the Department of Classical Philology in the newly created Poznan University. He was the

${ }^{30}$ Voevodskii L. Kannibalizm v grecheskikh mifakh: opyt po istorii razvitiia nravstvennosti. St. Petersburg, 1874.

31 Berezin S.E. Izuchenie antichnoi istorii v Novorossiiskom universitete: professor L.F. Voevodskii // Zapysky istorychnoho fakul'tetu. 2000. Iss. 10. P.61-62; Derevitskii A.N. L.F. Voevodskii (nekrolog) // ZhMNP. 1901. Iiul'. P.34-36.

32 Berezin S.E. Izuchenie antichnoi istorii... P. 62.

33 Voevodskii L. Vvedenie v mifologiiu Odissei. Ch. 1. Odessa, 1881.

34 Ibid. P. 98.

35 Berezin S. E. Izuchenie antichnoi istorii... P. 63. 
corresponding member (1922) and later the full member of the Polish Academy of Arts and Sciences $(1930)^{36}$.

Klinger was an expert in ancient folklore, an author of numerous publications on Greek poetry (especially lyrics) and historiography, a translator of the Greek lyric poetry, of Xenophon's "Hellenica", "Letters" by Julian the Apostate, and several treatises by Hippocrates. He also published studies on Polish literature. Klinger had acquired a wide range of research interests during Kievian period of his activity. At that time, he wrote such valuable works on folklore and ethnography as: "Skazochnye motivy v istorii Gerodota"37, "Zhivotnoe v antichnom i sovremennom sueverii"38, "Dve antichnye skazki ob orle i ikh pozdneishye otrazheniia" 39 , "Ambrozja i Styks a woda żywa i martwa" 40 etc. Studying ancient folklore, Klinger argued that Greece, not India as Theodore Benfey believed, was the original source of fairy tales, legends, stories and novels about animals. Thus, he deepened and broadened the research studies of German classical scholar Erwin Rohde ${ }^{41}$. While in Kiev, Klinger published works on Greek poets Archilochus and Semonides of Amorgos, on Alexandrian poetry and on the origin of Attic traged ${ }^{42}$, as well as "Philomath's Album" by Józef Kowalewski ${ }^{43}$.

Among Polish researchers in humanities there was also a historian of philosophy Henryk Jakubakis (1879-1949). Since 1907, he lectured at Zhekulina's Higher Women's Courses. In the following year, he became an Instructor, and then an Associate Professor (1917) at the Department of Philosophy at the University of St. Vladimir. After a mission abroad (1909-1912), Jakubakis lectured at the university, as well as at the Higher Women's Courses and Polish University Collegium in Kiev (1916-1918). After the revolution and civil war, he emigrated to Poland, where in 1922 he became a Professor at the Department of Classical Philology, and a year later - a Professor at the Department of Philosophy at Lublin Catholic University. During 1924/25 academic year, he was the Dean of the Faculty of Humanities ${ }^{44}$.

Kievian period was of particular importance in the professional life of Jakubanis. During that time he published his main works. The scholar's research interests included ancient philosophy, logic, and aesthetics. He consistently adhered to the culturological approach to the history of philosophy and used this approach while studying the world-

36 Klinger W. Życiorys własny // Meander. 1963. R. 18. No. 5. P.210-214; Steffen W.: 1) Pamięci Profesora Witolda Klingera // Meander. 1962. R. 17. No. 9. P. 404; 2) Klinger Witold (1875-1962) // Polski Słownik Biograficzny. T. XII. Wrocław [et al.], 1966-1967. P. 635-636; Wróblewski T. Profesor dr. Witold Klinger // Lud. 1962. Vol. 48. P.573-574.

37 Klinger V. Skazochnye motivy v istorii Gerodota. Kiev, 1903.

38 Klinger $V$. Zhivotnoe v antichnom i sovremennom sueverii. Kiev, 1911.

39 Klinger $V$. Dve antichnye skazki ob orle i ikh pozdneishye otrazheniia // Universitetskie izvestiia. 1913. No. 1. P. 1-25.

40 Klinger W. Ambrozja i Styks a woda żywa i martwa. Studium mitologiczno-porównawcze. Kraków, 1906.

41 Hammer S. Historia filologii klasycznej w Polsce. Kraków, 1948. P. 43-45; Grzegorczyk P. Z materiałów bio- i bibliograficznych pisarzy zmarłych w 1962 roku // Rocznik Literacki. 1862. R. 13. P. 523.

42 See: [Paprocki H.] Bibliografia publikacji prof. Witolda Klingera (1875-1962) // Symbolae Philologorum Posnaniensium Graecae et Latinae. 2015. Vol. XXV. Fasc. 2. P. 162-167.

43 Klinger W. Sztambuch filomaty. Kijów, 1916.

44 Tkachuk M. Iakubanis Henrikh-Roman Ivanovych // Filosofs'ka dumka v Ukraini. Biobibliohrafichnyi slovnyk. Kiev, 2002. P.238; Pastuszka J. Henryk Jakubanis (1879-1949). Wspomnienie pośmiertne // Roczniki Filozoficzne. 1949/1950. Vol.2/3. P.345-346; Klinger W. Jakubanis Henryk Roman (1879-1949) // Polski Słownik Biograficzny. T.X. Wrocław [et al.], 1962-1964. P. 374. 
view of ancient Greek thinker Empedocles ${ }^{45}$. Jakubanis found the key to Empedocles's "mystery" in the inner tragedy of the personality, caused by the "fatal ratio" between the general intellectual state of Hellas and the spirituality of the thinker ${ }^{46}$. The additional value of Jakubanis's monograph lies in providing his own versions of the translation of all of Empedocles's fragments known at the time in both verse and prose, with a critico-exegetical commentary. According to philosopher Alexander Makovelsky, the translation in verse was more artistic, and the one in prose was extremely precise ${ }^{47}$. The translation made by Jakubanis has been published repeatedly since.

\section{History of Western European Literature}

Two Polish professors specialized in the history of Western European literature. Leonard Kolmaczewski (1850-1889) was a historian of literature and a philologist. He was a lecturer in German language (since 1874), an Assistant Professor of the Department of World Literature (since 1883) and an Associate Professor at the Department of History of Western European Literature (since 1884) at Kazan University. In 1886, he moved to the similar department at Kharkov University, where he taught until $1889^{48}$.

Kołmaczewski's master's thesis "Zhivotnyi epos na zapade i u slavian" became his major work ${ }^{49}$. As a supporter of the 'theory of borrowings' (the so-called 'migration theory'), the scholar believed that the animal epos originated in the East, namely, in India, and began to spread into Europe through Byzantium even before the $5^{\text {th }}$ century BC. Consequently, Russian tales about animals originated either from East Byzantine, or from Western sources. In Kołmaczewski's opinion, the 'animal sagas' did not exist. First there was an 'animal' tale, and the fable was the development of a separate episode of such a tale. He explained the affinity between fairy tales about animals or their single motifs among the diverse peoples by uniform mental development, literary borrowing or by the dominance of oral tradition. At the same time, he supposed an independent origin of fairy tales: both in Europe and in other parts of the world. Kołmaczewski divided the plots of the Slavic tales about animals into nine main groups, considering that all other tales were more or less original versions of these groups. While in Kharkov, Kołmaczewski studied thoroughly the issue of authenticity of Ossian's poems. However, a serious disease and early death prevented him from finishing this work.

Leon Szepielewicz (1863-1909) was a historian of literature and archaeologist. He was an Associated Professor (1896-1904) and Full Professor (1904-1909) at the Department of History of Western European Literature of Kharkov University. The scholar had very broad research interests: he published works on Western European literature, as well

45 See: Tkachuk M. L. Istoryko-filosofs'ke antychnoznavstvo v Kyievi XIX - pochatku XX st. // Naukovi zapysky NaUKMA. Vol.21. Filosofiia ta relihiieznavstvo. 2003. P. 49-59.

46 Iakubanis G. Ėmpedokl filosof, vrach i charodei. Dannye dlia ego ponimaniia i otsenki. Kiev, 1906. P. 53-54.

47 Makovel'skii A. Dosokratiki. Pervye grecheskie mysliteli v ikh tvoreniiakh, v svidetel'stvakh drevnosti i v svete noveishikh issledovanii. Istoriko-kriticheskii obzor i perevod fragmentov, doksograficheskogo i biograficheskogo materiala Aleksandra Makovel'skogo. Ch. 2 (Ėleatovskii period). Kazan, 1915. P. V.

48 Solov'ev S. V. Kolmachevskii Leonard Zenonovich // Istoriko-filologicheskii fakul'tet Khar'kovskogo universiteta za pervye 100 let ego sushchestvovaniia (1805-1905) / eds M. G. Khalanskii, D. I. Bagalei. Kharkov, 1908. P. 239.

49 Kolmachevskii L. Zhivotnyi èpos na zapade i u slavian. Kazan, 1882. 
as on material and spiritual culture of Belarus ${ }^{50}$. In his early works Szepielewicz examined the issues of medieval West European literature. His master's thesis "Apokrificheskoe Videnie sv. Pavla" (Kharkov, 1891-1892) was highly appreciated by the specialists. In his doctoral thesis Szepielewicz studied German epic poem "Kudrun” (Kharkov, 1894-1895). The author came to the conclusion that the poem was of Bavarian origin and consisted of three independent parts. At the same time, he stressed the need to examine the strophes of "The Nibelungenlied" in order to determine the origin of the first part of the literary monument he analysed. At the end of the research Szepielewicz provided an excellent translation of the second part of "Kudrun" 51.

At the same time the scholar studied the contemporary Western European and Polish literature. He would regularly give public lectures on the relevant literary subjects. He devoted a series of these lectures to Henryk Sienkiewicz's novels. Subsequently, they became a part of the book "Nashi sovremenniki" (St. Petersburg, 1899), which also included sketches about Paul Bourget, Guy de Maupassant, Édouard Rod, Gerhart Hauptmann, and Émile Zola. On top of that, Szepielewicz also published articles on the history of Spanish literature, which became his favourite subject of research from 1898 and on. His painstaking study of the monuments of Spanish Renaissance literature resulted in two books: "Zhizn Servantesa i ego proizvedeniia" (Kharkov, 1901) and "Don Kikhot" Servantesa" (St. Petersburg, 1903), as well as articles about Cervantes and his time. These works were the first major research studies on the history of the Spanish Renaissance in Russia.

Szepielewicz was also focused on the issues of the contemporary Spanish and Portuguese literature. Moreover, he analyzed the writings of Shakespeare, Byron, Boccaccio, Erasmus of Rotterdam, Goethe and other authors. During the last years of his life, he studied the works of the $19^{\text {th }}$-century Italian poet Giosuè Carducci ${ }^{52}$. Finally, it is important to mention that Szepielewicz collaborated with Warsaw magazines "Ateneum", "Wisła" and "Przegląd Tygodniowy", and published notes in Polish in St. Petersburg newspaper "Kraj"53.

\section{World History}

There were two historians in the universities under study. Witold Nowodworski (1861-1923) was a specialist in the history of Poland and Polish-Russian relations. He taught History at First Cadet Corps (since 1885) and other secondary schools in St. Petersburg. Then, he served as an Instructor at the Faculty of History and Philology of St. Petersburg University (1900-1906). In 1906, Nowodworski became an Associate Professor at the Department of World History at Nezhin Prince Bezborodko Historical-Philological Institute. At the same time, he lectured at the University of St. Vladimir (since 1908), at Kiev Commercial Institute and at Zhekulina's Higher Women's Courses. During the years of the Russian revolution and civil war, Nowodworski actively participated in the Polish

50 Shepelevich L.Iu. Lazarevich-Shepelevich Lev-Mikhail Iulianovich // Istoriko-filologicheskii fakul'tet Khar'kovskogo universiteta za pervye 100 let ego sushchestvovaniia (1805-1905) / eds M. G. Khalanskii, D. I. Bagalei. Kharkov, 1908. P.241; Kijas A. Szepielewicz Leon Michał // Polski Słownik Biograficzny. T. XLVIII. Warszawa; Kraków, 2012-2013. P. 206-207.

51 Solovev S. L. Iu. Lazarevich-Shepelevich (Nekrolog) // ZhMNP. 1909. Mart. P. 38.

${ }^{52}$ Ibid. P. 39-40.

${ }^{53}$ Kijas A. Szepielewicz Leon Michał. P. 206. 
cultural and educational movement. The scholar was one of the co-founders of Polish University Collegium, where he gave lectures on the history of Poland and Lithuania. In 1921, he became a Professor at Stefan Batory University in Vilna ${ }^{54}$.

Nowodworski's master's thesis "Bor'ba za Livoniiu mezhdu Moskvoi i Rech'iu Pospolitoi (1570-1582). Istoriko-kriticheskoe issledovanie" is considered to be one of the best works of the historian, and is among the most valuable studies on this issue. The author described in detail the course of the Moscow-Polish confrontation and concluded that the Livonian War was an important phase in the political evolution of Eastern Europe. The war shattered the socio-political organization of the Moscow state and interrupted for a while its expansion towards the West. At the same time, the war greatly strengthened the position of Polish-Lithuanian Commonwealth in Eastern Europe ${ }^{55}$. Later Nowodworski continued to investigate the activities of the Polish King Stefan Batory and wrote several extensive publications on the life and activities of prominent Polish statesman, the Grand Hetman Jan Zamoysky ${ }^{56}$.

After moving to Nezhin, Nowodworski switched the focus of his research on world history, publishing a manual for the students on the history of Western Europe of the Early Modern period ${ }^{57}$. His interest in sociology and historiosophy resulted in a voluminous work on historical materialism, which ruthlessly criticized Karl Marx's theory ${ }^{58}$. In Nowodworski's opinion, that theory did not introduce any new creative elements and was only a one-sided development of the known historical concepts. The scholar's last publication was his introductory lecture on the essence and objects of the world history, which he delivered at the University of Stefan Batory on October 22, 1921. In this lecture Nowodworski pointed out that history, as a concrete science, should avoid risky hypotheses, especially metaphysical ones, and accept the recognition of various factors, which affect the development of mankind ${ }^{59}$.

Edmund Liwski (1817-1888) was a teacher at the district schools of Belaya Cerkov and Kupyansk, at Kharkov district school (since 1855) and Kharkov provincial gymnasium (since 1858). Over 1860-1862, he was an Assistant Professor at Kharkov University. His lectures on ancient history were popular among students. However, in view of the fact that Liwski failed to write his master's thesis, he was dismissed. He later taught in Kharkov secondary schools, and after his retirement in 1877, started to work as a publicist. Despite the ambitious plans and erudition, Liwski did not leave any substantial publications. He wrote short articles for Warsaw (mainly "Dziennik Warszawski”) and Lvov newspapers, for "Słownik geograficzny Królestwa Polskiego" and encyclopaedias. Some of his works

54 Samoilenko A. Istoriia i istoriki Pol'shy v nauchnom nasledii V. V. Novodvorskogo // Rocznik Instytutu Polsko-Rosyjskiego. 2012. No. 2. P.45-46, 50-52; Nowodworski W. Witold Nowodworski (18611923) jako teoretyk historii // Roczniki Humanistyczne. 1978. Vol. XXVI, iss. 2. P. 191-193.

55 Novodvorskii V. Bor'ba za Livoniiu mezhdu Moskvoi i Rech'iu Pospolitoi (1570-1582). Istoriko-kriticheskoe issledovanie. St. Petersburg, 1904. P.303.

56 Nowodworski W. Jan Zamojski, jego życie i działalność polityczna. Petersburg, 1898 etc.

57 Novodvorskii V. V. Istoriia Zapadnoi Evropy v nachale novogo vremeni (Proiskhozhdenie politicheskogo i sotsial'no-èkonomicheskogo stroia, srednevekovaia kul'tura, religioznaia zhizn', gumanizm). Posobie, izdannoe iskliuchitel'no dlia studentov Kievskogo kommercheskogo instituta. Kiev, 1914.

58 Novodvorskii V. V. Istoricheskii materializm. Doktrina Marksa i Ėngel'sa. Opyt istoriko-kriticheskogo issledovaniia // Izvestiia Istoriko-filologicheskogo instituta kniazia Bezborodko. 1914. Vol. 29. P. 1-112; 1916, vol. 31. P. 113-232; 1918, vol. 32. P. 233-300.

59 Nowodworski W. Istota i zadanie dziejów powszechnych. Wilno, 1924. P. 38. 
remained manuscripts, in particular, biographical sketches about different people related to the Basilian school in Uman, and to Kiev and Kharkov universities ${ }^{60}$.

\section{Roman Law}

During the period under review, six Polish lawyers worked in three universities: three in Kharkov University and three in Novorossiya University. Alekander Mickiewicz (18011871), the brother of Polish poet and publicist Adam Mickiewicz, specialized in the Roman Law. At the start of his career he lectured at Kremenets Lyceum (1828-1832). Later on, the scholar became the Associate Professor (1835) and Full Professor (1836) of Roman Law at the University of St. Vladimir. He served as the Full Professor at the Department of Roman Law (1838-1858) and the Dean (1849-1850) of the Faculty of Law at Kharkov University. In 1858, Mickiewicz left Kharkov and settled in Gubernia estate near Kobrin in Belorussian Polesie, not far from the place where he was born and spent his childhood.

Uneasy life circumstances, frequent redeployment, the need to alter lecture courses and to translate them from Polish and Latin into Russian were the main reasons why Mickiewicz left only a few publications. Among them, one should mention the student's work on the influence of Roman law on Polish and Lithuanian legislation (it was published in "Dziennik Warszawski" in 1825) and his master's thesis "De nominis pignore" (1827). Following his retirement, the scholar was preparing to publish the encyclopaedia of law and the course on Roman law, but these plans had never been realized. His course of lectures on Polish civil law and its history, which he delivered at Kremenets Lyceum in 1829, also remained a manuscript. Mickiewicz was unable to pursue his ideas because of health problems: in the last years of his life he lost his sight ${ }^{61}$.

Konrad Dynowski (1862-1930) was a well-known jurist and practitioner. Over 18891905, he had been the Instructor of Roman law at Novorossiya University, where he also taught the course on Russian civil law. The scholar served later as the Instructor at the Department of Russian Civil and Commercial Law and Legal Procedure at St. Petersburg University (1905-1910), and lectured at Alexander Lyceum. At the same time, Dynowski was a Member of Odessa District Court, a Member of Odessa Trial Chamber, a Legal Adviser to the Ministry of Justice and an Assistant of the Chief Prosecutor of the Cassation Department of the Senate, a Legal Advisor to the Ministry of Finance and a Consultant to the Ministry of Justice. A number of successful international legal proceedings are connected with the name of the scholar. After the revolution, Dynowski moved to Kiev, where

${ }^{60}$ Kijas A. Polacy na Uniwersytecie... S. 139-140; Dziwik K. Liwski Edmund // Polski Słownik Biograficzny. T.XVIII. Wrocław [et al.], 1972. P.500; Viazigin A. S. Livskii Ėdmund-Karl-Iulian Iosifovich // Istoriko-filologicheskii fakul'tet Khar'kovskogo universiteta za pervye 100 let ego sushchestvovaniia (1805-1905) / eds M. G. Khalanskii, D. I. Bagalei. Kharkov, 1908. P.281-282.

${ }^{61}$ Martseniuk R. Lytva - Ukraina - Lytva: zhyttievyi ta tvorchyi shliakh profesora Oleksandra Mitskevycha // Visnyk of Taras Shevchenko National University of Kyiv. Ser. History. 2016. No. 1 (128). P. 43-46; I-v E. Mitskevich Aleksandr Nikolaevich // Istoriko-filologicheskii fakul'tet Khar'kovskogo universiteta za pervye 100 let ego sushchestvovaniia (1805-1905) / eds M. G. Khalanskii, D. I. Bagalei. Kharkov, 1908. P. 171-172. Makowiecka Z. Mickiewicz Julian Aleksander (1801-1871) // Polski Słownik Biograficzny. T.XX. Wrocław [et al.], 1975. P.706. 
he had earlier graduated from the University of St. Vladimir. Since 1920, he had been the Professor at the Department of Civil Procedure at Warsaw University ${ }^{62}$.

The issues of Roman law, international law and Russian civil law were at the center of Dynowski's research interests. His main works were: "Zadachi tsivilisticheskogo obrazovaniia i znachenie ego dlia grazhdanskogo pravosudiia" ${ }^{63}$ and "Voprosy protsessual'noi politiki v dele voznagrazhdeniia sudebnykh pristavov po takse" 64 . The earlier publication contributed to the understanding of the importance of practice in legal education. Referring to the German experience of training lawyers, Dynowski wrote about the acute problems in the practical training in civil law, recognizing at the same time its sufficiency in the criminal law ${ }^{65}$. In the latter publication, the scholar revised a fee rate for bailiffs. In 1910, he published a work on the international procedural law, in which he examined the issue of inadmissibility of enforcement from the foreign countries ${ }^{66}$. It is important to add that the legal practice of Dynowski improved the civil justice and civic procedural norms in Russia.

\section{Encyclopaedia of Law and History of Russian Law}

Antoni Stanisławski (1817-1883) was a lawyer, translator and poet. Since 1843, he was the acting Assistant Professor, then the Assistant Professor (1844) and the Associate Professor (1852) of the Department of the Encyclopaedia of Law at Kazan University. In 1857, the scholar became the Full Professor of the similar department, and later the Dean of the Faculty of Law $(1858-1859,1866-1868)$ and Rector of Kharkov University (18661868). Over 1868-1879, Stanisławski had been the Full Professor of the Department of Encyclopaedia of Law at Kazan University, where he also served at the Department of State Law (1876-1879). In 1879, he moved to Warsaw ${ }^{67}$.

Stanisławski studied civil law and general theory of law. His master's and doctoral theses - "Ob aktakh ukrepleniia prav na imushchestva" (Kazan, 1842), "Issledovanie nachal imushchestvennykh otnoshenii $\mathrm{v}$ drevneishikh pamiatnikakh russkogo zakonodatelstva" (Kazan, 1855) - became his most significant works. The earlier one examined the issue of the gradual development and strengthening of the property law, and its impact on the development of society. In doctoral research, the scholar analysed and explained the

${ }^{62}$ Mioduszewski J. Dynowski Konrad (1862-1930) // Polski Słownik Biograficzny. T. VI. Wrocław [et al.], 1948. P. 67-68.

${ }^{63}$ Dynovskii K. Zadachi tsivilisticheskogo obrazovaniia i znachenie ego dlia grazhdanskogo pravosudiia. Odessa, 1896.

${ }^{64}$ Dynovskii K. Voprosy protsessual'noi politiki v dele voznagrazhdeniia sudebnykh pristavov po takse. Odessa, 1904.

${ }^{65}$ Dynovskii K. Zadachi tsivilisticheskogo obrazovaniia... P. 46.

${ }^{66}$ [Dynovsky C. von, Meili F., Laband P., Zorn P. et al.] Unzulässigkeit einer Zwangsvollstreckung gegen ausländische Staaten: Gutachten der Professoren Meili, Laband, Zorn... [u. a.] / eingeleitet und herausgegeben von C. V. Dynovsky. Berlin, 1910.

${ }_{67} \mathrm{Kr}$-ii F. Stanislavskii, Anton Grigor'evich // Russkii biograficheskii slovar'. T. XIX. St. Petersburg, 1909. P.316-317; [Zagurskii L. N.] Opyt istorii iuridicheskogo fakul'teta Imperatorskogo Khar'kovskogo universiteta // Iuridicheskii fakul'tet Khar'kovskogo universiteta za pervye sto let ego sushchestvovaniia (1805-1905) / eds M. P. Chubinskii, D. I. Bagalei. Kharkov, 1908. P. 47, 85; Zięba A. A. Stanisławski Robert Antoni // Polski Słownik Biograficzny. T. XLII. Warszawa; Kraków, 2003-2004. P. 106-108. 
texts of those articles of Oleg's and Igor's treaties with the Greeks and of "Russkaya Pravda" which contained references to the property rights of individuals ${ }^{68}$.

While in Kharkov, Stanisławski published his major work "O proiskhozhdenii polozhitelnogo prava" (1856). The researcher provided historical and legal analysis of the positive (i.e. set out in the legislation) law. He thoroughly reviewed the conclusions reached by Friedrich Carl von Savigny and his disciples, as well as the differences that emerged between them and the representatives of Roman school of law. Stanisławski was one of the first Russian lawyers who raised the question of the relationship between natural (philosophical) and positive law. He defined the concept of natural law as the rights that belong to the entire human race, and the positive law as a set of rules which are mandatory for a particular people, drawing on the works of Leopold Warnkönig and Georg Hegel. The researcher belonged to the historical school of law, but in reality he proposed a synthesis of philosophical and positive law. The concept of the law formulated by Stanisławski differed from the concept of positive law, particularly owing to the fact that it did not completely separate law and morality. On the contrary, this concept declared the moral law a basis for the universal element in law ${ }^{69}$.

It is worth mentioning that in 1857 Stanisławski initiated the translation of Dante Alighieri's "The Divine Comedy" into Polish in blank verse. The translation with valuable annotation and comments was published in Dresden in 1870 under the supervision of a famous Polish writer Józef Kraszewski. The book received a favourable reception from Polish critics. The second edition of the translation was published in Krakow in 1887. Stanisławski also wrote poems, songs, and dumas in Polish; some of them appeared in Polish publications ${ }^{70}$.

Jan Sobestyjański (1856-1895) was a historian of Slavic law. He served in Tiflis Trial Chamber (1878-1879); later he became the Instructor (since 1887), the acting Associate Professor (since 1890) and Full Professor (since 1893) at the Department of the History of Russian Law at Kharkov University ${ }^{71}$. The researcher focused mainly on the legal life of ancient Slavs, and at the same time analysed their national character and customs. His master's thesis studied the institution of esprit de corps among the Slavs ${ }^{72}$. The author critically evaluated the works of František Palacký, Nikolai Ivanishev, Wacław Aleksander Maciejowski and others, reproaching them for the use of falsified monuments and a priori contraposition of Slavic law to Germanic. Sobestyjański rethought the achievements of the school of Slavic law and came to the conclusion that esprit de corps of tribal and territorial unions was not unique to the Slavs. It was common among many peoples until the $19^{\text {th }}$ century. In the scholar's opinion, the institution of esprit de corps was a product of a certain level of social development and did not have a national specificity ${ }^{73}$.

${ }^{68} \mathrm{Kr}$-ii F. Stanislavskii, Anton Grigor'evich. P. 316-317.

${ }^{69}$ Pustarnikov V.F. Universitetskaia filosofiia v Rossii. Idei. Personalii. Osnovnye tsentry. St. Petersburg, 2003. P.612.

70 Zięba A. A. Stanisławski Robert Antoni. P. 107-108.

${ }^{71}$ Bandurka O.M., Hrechenko V.A. Naukovyi dorobok istoryka prava I. M. Sobestians'koho (18561895 rr.) // Pravo.ua. 2018. No. 1. P. 6.

${ }_{72}$ Sobestianskii I.M. Krugovaia poruka u slavian po drevnim pamiatnikam ikh zakonodatel'stva. Kharkov, 1888.

${ }^{73}$ Drinov M. Obzor uchenoi deiatel'nosti Ivana Mikhailovicha Sobestianskogo // Ivan Mikhailovich Sobestianskii (rod. 5 sent. 1856 g., $\dagger 8$ dek. 1895 g.). S prilozheniem portreta. Kharkov, 1896. P. 8-9. 
Sobestyjański's doctoral thesis received a considerable response ${ }^{74}$. In the first part of this work, the author examined the views scholars had on the character and temper of ancient Slavs. Sobestyjański believed that a balanced view of the Slavs' history had been dominant until the $18^{\text {th }}$ century. Slavists of that time did not point out special national character traits among the Slavs and emphasized that militancy, bravery and cruelty were inherent to all primitive peoples. Herder's "Ideas for the Philosophy of the History of $\mathrm{Hu}$ manity" provided a decisive influence on further development of Slavic historiography. In this work, German philosopher presented Slavs as peaceful people who avoided violence. Herder's theory contributed to the Slavic revival, but at the same time, in Sobestyjański's opinion, it set the Slavic history studies 'on a false track'. The second part of the thesis examined the teachings about national peculiarities of the legal life of ancient Slavs. The author also analysed the sources in this part of his work and came to the conclusion that legal life of the ancient Slavs resembled the life of Germans, and that the democratic principles of freedom, equality and fraternity virtually didn't exist in the lives of ancient Slavs and Germans. However, the majority of Russian scholars did not accept the basic ideas of Sobestyjański's monograph; criticism prevailed over the positive assessments. Foreign researchers, on the contrary, viewed the book favourably, emphasizing the importance of Sobestyjański’s discoveries ${ }^{75}$.

\section{Civil Law and Civil Procedure}

Eugeniusz Waśkowski (1866-1942) was a famous specialist in civil law and procedure, a lawyer and a judge. For ten years he practised law in Odessa. Then, he became an Instructor (1897-1904), Associate Professor (1904-1906) and Full Professor (1906-1909) of the Department of Civil Law and Civil Procedure, and since 1906 - the Pro-rector of Novorossiya University. In 1909, Waśkowski was removed from his post on charges of not taking repressive measures against students in 1905-1906. In 1917, he was reinstated as the Full Professor at the same department and was elected the Dean of the Faculty of Law. The scholar held these positions until 1920. Later he worked as the Professor and the Pro-rector of the Odessa Humanitarian and Social Institute (1920) and Odessa Institute of Public Education (1921-1924). After emigration, Waśkowski became the Full Professor of the Department of Civil Law (1924-1939) and the Dean of the Faculty of Law (1925/26 academic year) at Stefan Batory University in Vilna. In 1938, he was elected the Corresponding Member of Polish Academy of Arts and Sciences ${ }^{76}$.

Waśkowski's research interests covered the problems of civil law and civil procedure, maritime trade law, history, organizational, legal and ethical fundamentals of advocacy, the judicial system issues, and the methodology of jurisprudence. On top of that, he translated into Russian the work of Hippolyte Taine "Les Philosophes français du xix siècle" and Rudolf von Jhering's "Der Besitzwille". The first major work of Waśkowski was the

74 Sobestianskii I. M. Ucheniia o natsional'nykh osobennostiakh kharaktera i iuridicheskogo byta drevnikh slavian: istoriko-kriticheskoe issledovanie. Kharkov, 1892.

75 Drinov M. Obzor uchenoi deiatel'nosti Ivana Mikhailovicha Sobestianskogo. P. 9-13.

${ }^{76}$ Kanzafarova I. S., Podrezova M. A. Evgenii Vladimirovich Vas'kovskii: stranitsy zhizni i nauchnogo tvorchestva // Pravovoe regulirovanie otnoshenii v sfere chastnogo prava: traditsii i sovremennost'. Odessa, 2016. P. 7-12; Radzik A. Eugeniusz Waśkowski (1866-1942). W siedemdziesięciolecie śmierci wybitego uczonego i adwokata // Palestra. 2012. No. 9-10. P.256-267. 
book about the organisation of the $\mathrm{Bar}^{77}$, which he defended as his master's thesis in 1897 . The author examined the history of the establishment of the advocacy in Greece, Rome, France, England, Germany, Austria, Russia, Belgium, Holland, Italy, USA, and other countries. He also analysed the state of the contemporary Russian advocacy and formulated a number of recommendations on how to correct the problems in its organisation and operation which he saw.

Soon, Waśkowski published a textbook "Uchebnik grazhdanskogo prava" (two issues, 1894-1896) and a book "Osnovnye voprosy advokatskoi ettiki" (1895). In 1901, he defended his doctoral thesis on the very unusual topic: "Tsivilisticheskaia metodologiia: Uchenie o tolkovanii i primenenii grazhdanskikh zakonov". The reviews of this work by legal scholars were mixed. Although they praised certain chapters of the research, their opinion about the book in general was rather critical. However, according to modern specialists in civil law, this work is the best with regard to theory and practice of interpretation of legislative regulations ${ }^{78}$.

In 1913, Waśkowski published "Kurs grazhdanskogo protsessa" (vol. 1) and "Rukovodstvo k tolkovaniiu i primeneniiu zakonov dlia nachinaiushchikh iuristov". The first edition of "Uchebnik grazhdanskogo protsessa" came out in 1914, and the second one appeared in 1917. The latter one has been repeatedly republished in the USSR and Russia ${ }^{79}$. His contemporaries called Waśkowski's work the best textbook on civil process ${ }^{80}$. After moving to Poland, the scholar continued his researches and published a number of serious educational and academic works in Polish.

\section{Political Economy and Statistics}

Leon Fiedorowicz (1854-1908) was an economist, specialist in political economy and statistics, a supporter of the historical school and social direction in political economy ${ }^{81}$. He was the Assistant (since 1884), Associate Professor (1888) and Full Professor (1890) at the Department of Political Economy and Statistics at Novorossiya University. In 1908, Fiedorowicz finished his career after reaching the end of the required service ${ }^{82}$.

The scholar's research interests included a wide range of topics - from the issues of value to credit policy. In 1881, Fiedorowicz defended his master's thesis, which examined new factory legislation. The author showed the importance of housing to improve everyday life and to form physical and moral qualities of workers. He also proved that state authorities must intervene in the solution of the housing problem in order to soften class antagonisms ${ }^{83}$. In 1888, Fiedorowicz defended his doctoral thesis on the theory of mone-

77 Vas'kovskii E. V. Organizatsiia advokatury. In 2 vols. St. Petersburg, 1893.

78 Kanzafarova I. S., Podrezova M. A. Evgenii Vladimirovich Vas'kovskii: stranitsy zhizni i nauchnogo tvorchestva. P. 13.

79 Ibid.

80 Bugaevskii A. E. V.Vas'kovskii. Uchebnik grazhdanskogo protsessa. Moskva. 1914 g. Str. X+571. Tsena 3 r. 50 k. [retsenziia] // Pravo. 1914. No. 10. Column 803-805; Iablochkov T. E. V. Vas'kovskii. Uchebnik grazhdanskogo protsessa. Moskva. 1914 g. Stran. 571. Ts. 3 rub. 50 kop. [retsenziia] // Iuridicheskii vestnik. 1914. Vol. V (I). P. 294-296.

${ }^{81}$ Khmeliarchuk M. I. Svitovi tsinnosti ukrains'koi ekonomichnoi dumky v rozvytku monetarnoi teorii // Visnyk Universytetu bankivs'koi spravy Natsional'noho banku Ukrainy. 2008. Hruden'. No. 3. P. 37.

82 Takhtarova N. S. Fedorovych Lev (Leon) Vasyl'ovych // Profesory Odes'koho (Novorosiis'koho) universytetu. Biohrafichnyi slovnyk. T. 4. Odessa, 2000. P. 283.

${ }^{83}$ Fedorovich L. Zhilye pomeshcheniia rabochikh. St. Petersburg, 1881. 
tary policy ${ }^{84}$. The researcher explored in detail the nature, essence and value of money, revealed patterns and evolution of money turnover. He defended the advantages of the metal monetary system and suggested various ways of returning to it. The other major works by the scholar were "Istoriia i teoriia statistiki" (Odessa, 1894), "Teoriia politicheskoi ekonomii" in two parts (Odessa, 1901) and "Kurs politicheskoi ekonomii" (Odessa, 1905). Fiedorowicz also wrote one of the first training courses on the history of economic doctrines, which was published under the title "Istoriia politicheskoi ekonomii s drevneishikh vremen do A. Smita" (Odessa, 1900).

\section{Conclusion}

Thus, the complex political situation in the country after the Polish insurrection of $1863 / 64$ and the subsequent tightening of the restrictions on the selection of academics did not block the way for Poles to Kiev, Kharkov and Novorossiya universities. Each scholar made an important contribution to further development of Russian humanities and jurisprudence. The most significant group of Polish scholars were the specialists in classical philology (five professors). To some extent, a study of the distant historical epochs can be explained by the desire to disengage from the actual political situation in the country and from assessment of the developments of the recent past. An interesting observation follows the analysis of works of this group of researchers. They concentrated mainly on the themes of Ancient Greece, studying ancient Greek poetry, history, historiography, folklore, mythology, and morality. Jakubanis, who was a specialist in history of ancient Greek philosophy, should also be included into the group of professors that studied the antiquity. The next largest groups (two academics in each) represented Western European literature, world history, and Roman law. The encyclopaedia of law, the history of Russian law, civil law and civil procedure, political economy and statistics were represented by a different Polish academic each.

Alongside the studies on the subject of their specialization, some researchers were also engaged in translations. They did translations from Greek, German, Italian, French, English, and Swedish into both Russian and Polish. Such an interest was to some extent conditioned by the fact that translated works were not subjected to strict censorship, and it was easier to publish them. The publications of translated works greatly enriched Russian and Polish science and helped to popularize the famous works of foreign poets, philosophers and scholars. Thus, the Polish researchers in humanities who worked at Kiev, Kharkov and Novorossiya universities made a tangible contribution to the study of classical philology, literature, history, and jurisprudence. Further exploration of this issue will allow creating a holistic picture of the contribution of the Polish scientific thought to the development of humanities and jurisprudence in the Russian Empire.

\section{References}

Bandurka O. M., Hrechenko V. A. Naukovyi dorobok istoryka prava I. M. Sobestians'koho (1856-1895 rr.). Pravo.ua, 2018, no. 1, pp. 5-11. (In Ukrainian)

Berezin S.E. Izuchenie antichnoi istorii v Novorossiiskom universitete: professor L. F. Voevodskii. Zapysky istorychnoho fakul'tetu, 2000, iss. 10, pp. 59-65. (In Russian).

${ }^{84}$ Fedorovich L. V. Teoriia denezhnogo i kreditnogo obrashcheniia. Odessa, 1888. 
Berezin S. Ie., Izbash T. O. Voievods'kyi Leopol'd Frantsevych. Profesory Odes'koho (Novorosiis'koho) universytetu. Biohrafichnyi slovnyk. T.2. Odessa, AstroPrint, 2000, pp. 233-234. (In Ukrainian)

Berezin S. Ie. Novi materialy do biohrafii L. F. Voievods'koho. Zapysky istorychnoho fakul'tetu, 2016, iss. 27, pp. 466-487. (In Ukrainian)

Błaszczyk G. Pierwsi Polacy na Uniwersytecie Dorpackim w latach 1802-1832. Kwartalnik Historii Nauki $i$ Techniki, 2007, R. 52. No. 3-4, pp. 185-223.

Bugaevskii A.E. V. Vas'kovskii. Uchebnik grazhdanskogo protsessa. Moskva. 1914 g. Str. X+571. Tsena 3 r. 50 k. [retsenziia]. Pravo, 1914, no. 10, column 803-805. (In Russian)

[D’omin O. B.] Evoliutsiia istorychnoi nauky. Odes'kyi natsional'nyi universytet imeni I. I. Mechnykova. Istoriia ta suchasnist' (1865-2015). Ed. by I. M. Koval'. Odessa, Odessa National University Press, 2015, pp. 120-146. (In Ukrainian)

D’omin O. Pol's'ka profesura Novorosiis'koho universytetu (1865-1920 rr.). Poliaky na Pivdni Ukrainy = Polacy na Poludniowej Ukrainie. Science eds T.Tsysel's'kyi, V.H.Kushnir. Odessa [et al.], Hermes, 2006, pp. 157-159. (In Ukrainian)

De-Pule M. Khar'kovskii universitet i D. I. Kachenovskii. Vestnik Evropy, 1874, no. I, pp. 75-115. (In Russian)

Derevitskii A.N. L.F. Voevodskii (nekrolog). Zhurnal ministerstva narodnogo prosveshcheniia, 1901, iiul', pp.32-38. (In Russian)

Derevitskii A. O. I. Pekhovskii (nekrolog). Filologicheskoe obozrenie, 1891, vol. 1, pp. 212-215. (In Russian)

Drinov M. Obzor uchenoi deiatel'nosti Ivana Mikhailovicha Sobestianskogo. Ivan Mikhailovich Sobestianskii (rod. 5 sent. 1856 g., $\$ 8$ dek. 1895 g.). S prilozheniem portreta. Kharkov, Kharkov Historical and Philological Society, 1896, pp. 6-16. (In Russian)

Dynovskii K. Voprosy protsessual'noi politiki $v$ dele voznagrazhdeniia sudebnykh pristavov po takse. Odessa, KAPARI's successors, 1904, 28 p. (In Russian)

Dynovskii K. Zadachi tsivilisticheskogo obrazovaniia i znachenie ego dlia grazhdanskogo pravosudiia. Odessa, "Slavianskaia" of N. Khrisogelos, 1896, 64 p. (In Russian)

[Dynovsky von C., Meili F., Laband P., Zorn P. et al.] Unzulässigkeit einer Zwangsvollstreckung gegen ausländische Staaten: Gutachten der Professoren Meili, Laband, Zorn... [u. a.]. Eingeleitet und herausgegeben von C. v. Dynovsky. Berlin, Prager, 1910, XXXII, 369, [1] p.

Dziwik K. Liwski Edmund. Polski Słownik Biograficzny. T.XVIII. Wrocław [et al.], Polish Academy of Sciences, 1972, pp. 500-501.

Fedorovich L. V. Teoriia denezhnogo i kreditnogo obrashcheniia. Odessa, Tip. "Odesskii vestnik", 1888, 627 p. (In Russian)

Fedorovich L. Zhilye pomeshcheniia rabochikh. St. Petersburg, R. Golike, 1881, VI, 347 p. (In Russian)

Grzegorczyk P. Z materiałów bio- i bibliograficznych pisarzy zmarłych w 1962 roku. Rocznik Literacki, 1862, R. 13, pp. 518-531.

Hammer S. Historia filologii klasycznej w Polsce. Kraków, Polish Academy of Learning, 1948, 93 p.

I-v E. Mitskevich Aleksandr Nikolaevich. Istoriko-filologicheskii fakul'tet Khar'kovskogo universiteta za pervye 100 let ego sushchestvovaniia (1805-1905). Eds M. G. Khalanskii, D. I. Bagalei. Kharkov, A. Darre, 1908, pp. 171-172. (In Russian)

Iablochkov T. E. V. Vas'kovskii. Uchebnik grazhdanskogo protsessa. Moskva. 1914 g. Stran. 571. Ts. 3 rub. 50 kop. [retsenziia]. Iuridicheskii vestnik, 1914, vol. V (I), pp. 294-296. (In Russian)

Iakubanis G. Ėmpedokl filosof, vrach $i$ charodei. Dannye dlia ego ponimaniia i otsenki. Kiev, Imperial University of St. Vladimir, 1906, [4], 184 pp. (In Russian)

Kanzafarova I. S., Podrezova M. A. Evgenii Vladimirovich Vas'kovskii: stranitsy zhizni i nauchnogo tvorchestva. Pravovoe regulirovanie otnoshenii v sfere chastnogo prava: traditsii i sovremennost'. Odessa, Astroprint, 2016, pp. 7-16. (In Russian)

Khmeliarchuk M. I. Svitovi tsinnosti ukrains'koi ekonomichnoi dumky v rozvytku monetarnoi teorii. Visnyk of the University of Banking of the National Bank of Ukraine, 2008, hruden', no. 3, pp. 37-40. (In Ukrainian)

Kijas A. Polacy na Uniwersytecie Charkowskim 1805-1917. Wydanie drugie poprawione i uzupełnione. Poznań, Wydawnictwo Poznańskiego Towarzystwa Przyjaciół Nauk, 2008, 284 p. (Poznańskie Towarzystwo Przyjaciół Nauk. Wznowienia. T.30).

Kijas A. Polscy profesorowie na Uniwersytecie Charkowskim do 1917 roku. Wrocławskie Studia Wschodnie, 2011, no. 15, pp. 47-64.

Kijas A. Szepielewicz Leon Michał. Polski Słownik Biograficzny. T. XLVIII. Warszawa; Kraków, National Programme for the Development of Humanities, 2012-2013, pp. 206-207. 
Klinger V. Dve antichnye skazki ob orle i ikh pozdneishye otrazheniia. Universitetskie izvestiia, 1913, no. 1, pp. 1-25. (In Russian)

Klinger V. Skazochnye motivy v istorii Gerodota. Kiev, Imperial University of St. Vladimir, 1903, 222 p. (In Russian)

Klinger V. Zhivotnoe v antichnom i sovremennom sueverii. Kiev, Imperial University of St. Vladimir, 1911, 368 p. (In Russian)

Klinger W. Ambrozja i Styks a woda żywa i martwa. Studium mitologiczno-porównawcze. Kraków, Academy of Learning, 1906, pp. 313-480.

Klinger W. Jakubanis Henryk Roman (1879-1949). Polski Słownik Biograficzny. T.X. Wrocław [et al.], National Ossoliński Institute, Polish Academy of Sciences, 1962-1964, p. 374.

Klinger W. Sztambuch filomaty. Kijów, Słowiańska, 1916, 29 p.

Klinger W. Życiorys własny. Meander, 1963, R. 18, no. 5, pp. 210-214.

Kolmachevskii L. Zhivotnyi eppos na zapade i u slavian. Kazan', Imperial University, 1882, 316 p. (In Russian)

$\mathrm{Kr}$-ii F. Stanislavskii, Anton Grigor'evich. Russkii biograficheskii slovar'. T. XIX. St. Petersburg, Tovarishchestvo "Obshchestvennaia Pol'za", 1909, pp. 316-318. (In Russian)

Kuznetsov V. O. Vnesok pol's'koi intelihentsii u rozvytok mikrobiolohichnoi naukovoi shkoly v Odes'komu (Novorosiis'komu) universyteti imeni I. I. Mechnykova. Poliaky na Pivdni Ukrainy ta $v$ Krymu = Polacy na Południowej Ukrainie i Krzymie. Eds T. Tsysel's'kyi, E. Chapevs'kyi, V. Kushnir. Odessa [et al.], Hermes, 2007, pp. 264-276. (In Ukrainian)

Lisevych I. T. U zatinku dvohlavoho orla (pol's'ka natsional'na menshyna na Nadniprians'kii Ukraini v druhii polovyni XIX - na pochatku XX st.). Kiev, Institute of the History of Ukraine, Academy of Sciences of Ukraine, 1993, 87 p. (In Ukrainian)

Makovel'skii A. Dosokratiki. Pervye grecheskie mysliteli v ikh tvoreniiakh, v svidetel'stvakh drevnosti i v svete noveishikh issledovanii. Istoriko-kriticheskii obzor i perevod fragmentov, doksograficheskogo i biograficheskogo materiala Aleksandra Makovel'skogo. Ch. 2 (Ėleatovskii period). Kazan, M. A. Golubev's, 1915, X, 242 p. (In Russian)

Makowiecka Z. Mickiewicz Julian Aleksander (1801-1871). Polski Słownik Biograficzny. T.XX. Wrocław [et al.], National Ossoliński Institute, Polish Academy of Sciences, 1975, p. 706.

Martseniuk R. Lytva - Ukraina - Lytva: zhyttievyi ta tvorchyi shliakh profesora Oleksandra Mitskevycha. Visnyk of Taras Shevchenko National University of Kyiv. Ser. History, 2016, no. 1 (128), pp. 42-48. (In Ukrainian)

Martseniuk R. Poliaky v Universyteti sv. Volodymyra (1834-1839): problemy kul'turnoi adaptatsii. Acta Polono-Ruthenica, 2011, no. 16, pp. 89-101. (In Ukrainian)

Marushkina I. M. Nauchno-prepodavatel'skaia deiatel'nost' pol'skikh uchenykh v universitetakh Ukrainy (konets XIX - nachalo XX v.). Kul'turnye i obshchestvennye sviazi Ukrainy so stranami Evropy. Kiev, Naukova Dumka, 1990, pp. 195-211. (In Russian)

Maslov M. A. Valitskii Al'fons Osipovich. Istoriko-filologicheskii fakul'tet Khar'kovskogo universiteta za pervye 100 let ego sushchestvovaniia (1805-1905). Eds M. G. Khalanskii, D. I. Bagalei. Kharkov, A. Darre, 1908, pp. 175-183. (In Russian)

Mioduszewski J. Dynowski Konrad (1862-1930). Polski Słownik Biograficzny. T. V. Wrocław [et al.], Polish Academy of Learning, 1948, pp. 67-68.

Netushil I. Osip Ivanovich Pekhovskii: Obozrenie ego ucheno-literaturnoi deiatel'nosti i biograficheskie dannye. Kharkov, Zil'berberg, 1902, 36 p. (In Russian)

Netushil I. V. Pekhovskii Osip Ivanovich. Istoriko-filologicheskii fakul'tet Khar'kovskogo universiteta za pervye 100 let ego sushchestvovaniia (1805-1905). Eds M. G. Khalanskii, D. I. Bagalei. Kharkov, A. Darre, 1908, pp. 200-202. (In Russian)

Novodvorskii V. Bor'ba za Livoniiu mezhdu Moskvoi i Rech'iu Pospolitoi (1570-1582). Istoriko-kriticheskoe issledovanie. St. Petersburg, I. N. Skorokhodov, 1904, II, 304, 50 p. (In Russian)

Novodvorskii V. V. Istoricheskii materializm. Doktrina Marksa i Engel'sa. Opyt istoriko-kriticheskogo issledovaniia. Izvestiia Istoriko-filologicheskogo instituta kniazia Bezborodko, 1914, vol. 29, pp. 1-112; 1916, vol. 31, pp. 113-232; 1918, vol. 32, pp. 233-300. (In Russian)

Novodvorskii V.V. Istoriia Zapadnoi Evropy v nachale novogo vremeni (Proiskhozhdenie politicheskogo $i$ sotsial'no-ekonomicheskogo stroia, srednevekovaia kul'tura, religioznaia zhizn', gumanizm). Posobie, izdannoe iskliuchitel'no dlia studentov Kievskogo kommercheskogo instituta. Kiev, Obshchestvo vzaimopomoshchi studentov Kievskogo kommercheskogo instituta, 1914, 188 p. (In Russian)

Nowodworski W. Istota i zadanie dziejów powszechnych. Wilno, Księgarnia Stowarzyszenia Nauczycielstwa Polskiego w Wilnie, 1924, 43 p. 
Nowodworski W. Jan Zamojski, jego życie i działalność polityczna. Petersburg, Nakładem K. Grendyszyńskiego, 1898, $98 \mathrm{p}$.

Nowodworski W. Witold Nowodworski (1861-1923) jako teoretyk historii. Roczniki Humanistyczne, 1978, vol. XXVI, iss. 2, pp. 191-232.

Orgelbrand S. Encyklopedyja powszechna. T. XXVI. Uła - Wikaryusz. Warszawa, S. Orgelbrand Print., 1867, 983, IX p.

[Paprocki H.] Bibliografia publikacji prof. Witolda Klingera (1875-1962), opracował Henryk Paprocki. Symbolae Philologorum Posnaniensium Graecae et Latinae, 2015, vol. XXV, fasc. 2, pp. 162-200.

Pastuszka J. Henryk Jakubanis (1879-1949). Wspomnienie pośmiertne. Roczniki Filozoficzne, 1949/1950, vol. 2/3, pp. 344-346.

Piechowski J. De ironia Iliadis. Mosquae, Typis Universitatis Caesareae, 1856, 172 p.

Piechowski J. De Q. Horatii Flacci Epistola ad Pisones. Mosquae, Typis Universitatis Caesareae, 1853, 159 p.

Piechowski J. Sylwetki filologów klasycznych w Polsce: Józef Piechowski 1815-1891. Meander, 1853, R. IX, no. 3, pp. 142-144.

Pustarnikov V. F. Universitetskaia filosofiia v Rossii. Idei. Personalii. Osnovnye tsentry. St. Petersburg, Russian Christian Humanities Institute Press, 2003, 919 p. (In Russian)

Radzik A. Eugeniusz Waśkowski (1866-1942). W siedemdziesięciolecie śmierci wybitego uczonego i adwokata. Palestra, 2012, no. 9-10, pp. 255-267.

Róziewicz J. Polsko-rosyjskie powiązania naukowe (1725-1918). Wrocław [et al.], National Ossoliński Institute, Polish Academy of Sciences, 1984, 347 p.

Rys dziejów literatury polskiej, podług notat A. Zdanowicza oraz innych źródeł, opracował i do ostatnich czasów doprowadził L. Sowiński. T. IV. Wilno, Nakładem i drukiem J.Zawadzkiego, 1877. XI, [5], 837 p.

Samoilenko A. Istoriia i istoriki Pol'shy v nauchnom nasledii V. V. Novodvorskogo. Rocznik Instytutu Polsko-Rosyjskiego, 2012, no. 2, pp. 42-54. (In Russian)

Shamanaev A. V. Vklad V. N. Iurgevicha v izuchenie i sokhranenie pamiatnikov Kryma. Antichnaia drevnost' i srednie veka, 2011, iss. 40, pp. 409-421. (In Russian)

Shepelevich L.Iu. Lazarevich-Shepelevich Lev-Mikhail Iulianovich. Istoriko-filologicheskii fakul'tet Khar'kovskogo universiteta za pervye 100 let ego sushchestvovaniia (1805-1905). Eds M. G. Khalanskii, D. I. Bagalei. Kharkov, A. Darre, 1908, pp. 239-241. (In Russian)

Sobestianskii I. M. Krugovaia poruka u slavian po drevnim pamiatnikam ikh zakonodatel'stva. $2^{\text {nd }}$ ed. Kharkov, M.F.Zil'berberg, 1888, 158, VIII p. (In Russian)

Sobestianskii I.M. Ucheniia o natsional'nykh osobennostiakh kharaktera i iuridicheskogo byta drevnikh slavian: istoriko-kriticheskoe issledovanie. Kharkov, A. N. Gusev, 1892. IV, 336, XII p. (In Russian)

Solov'ev S. L. Iu. Lazarevich-Shepelevich (Nekrolog). Zhurnal Ministerstva narodnogo prosveshcheniia, 1909, mart, pp. 36-44. (In Russian)

Solov'ev S. V. Kolmachevskii Leonard Zenonovich. Istoriko-filologicheskii fakul'tet Khar'kovskogo universiteta za pervye 100 let ego sushchestvovaniia (1805-1905). Eds M. G. Khalanskii, D. I. Bagalei. Kharkov, A. Darre, 1908, pp. 239-241. (In Russian)

Steffen W. Klinger Witold (1875-1962). Polski Słownik Biograficzny. T. XII. Wrocław [et al.], National Ossoliński Institute, Polish Academy of Sciences, 1966-1867, pp. 635-636.

Steffen W. Pamięci Profesora Witolda Klingera. Meander, 1962, R. 17, no. 9, pp. 403-406.

Tabis J. Polacy na Uniwersytecie Kijowskim, 1834-1863. Kraków, Wydawnictwo Literackie, 1974, 198 p.

Takhtarova N.S. Fedorovych Lev (Leon) Vasylovych. Profesory Odes'koho (Novorosiis'koho) universytetu. Biohrafichnyi slovnyk. T.4. Odessa, Astroprint, 2000, pp. 282-284. (In Ukrainian)

Tkachuk M. Iakubanis Henrikh-Roman Ivanovych. Filosofs'ka dumka v Ukraini. Biobibliohrafichnyi slovnyk. Kiev, "PUL'SARY”, 2002, pp. 238-239. (In Ukrainian)

Tkachuk M. L. Istoryko-filosofs'ke antychnoznavstvo v Kyievi XIX — pochatku XX st. Naukovi zapysky NaUKMA. Vol.21. Filosofiia ta relihiieznavstvo, 2003, pp. 49-59. (In Ukrainian)

V.R. V. N. Iurgevich (nekrolog). Zhurnal Ministerstva narodnogo prosveshcheniia, 1899, ianvar', pp. 81-83. (In Russian)

Vas'kovskii E.V. Organizatsiia advokatury. T.1. Ocherk vseobshchei istorii advokatury. St. Petersburg, N. K. Martynov, 1893, VIII, 396 p.; T. 2. Issledovanie printsipov organizatsii advokatury. St. Petersburg, M. M. Stasiulevich, 1893, [2], 213 p. (In Russian)

Vasil'ev K. Poliaki v Odesse: vrachi i farmatsevty (do 1920 g.). Poliaky na Pivdni Ukrainy = Polacy na Południowej Ukrainie. Science eds T. Tsysel's'kyi, V.H. Kushnir. Odessa [et al.], Hermes, 2006, pp. 111123. (In Russian) 
Viazigin A.S. Livskii Ėdmund-Karl-Iulian Iosifovich. Istoriko-filologicheskii fakul'tet Khar'kovskogo universiteta za pervye 100 let ego sushchestvovaniia (1805-1905). Eds M. G. Khalanskii, D. I. Bagalei. Kharkov, A. Darre, 1908, pp. 281-282. (In Russian)

Voevodskii L. Kannibalizm v grecheskikh mifakh: opyt po istorii razvitiia nravstvennosti. St. Petersburg, V.S. Balashev, 1874, [8], 397, 2 p. (In Russian)

Voevodskii L. Vvedenie v mifologiiu Odissei. Ch. 1. Odessa, P. A.Zelenyi, 1881, 235 p. (In Russian)

Wróblewski T. Profesor dr. Witold Klinger. Lud, 1962, vol. 48, pp. 571-577.

[Zagurskii L. N.] Opyt istorii iuridicheskogo fakul'teta Imperatorskogo Khar'kovskogo universiteta. Iuridicheskii fakul'tet Khar'kovskogo universiteta za pervye sto let ego sushchestvovaniia (1805-1905). Eds M. P. Chubinskii, D. I. Bagalei. Kharkov, "Pechatnoe delo", 1908, pp. 1-162. (In Ukrainian)

Zięba A. A. Stanisławski Robert Antoni. Polski Stownik Biograficzny. T. XLII. Warszawa; Kraków, Wydawnictwo Towarzystwa Naukowego SOCIETAS VISTULANA, 2003-2004, pp. 106-110.

Received: July 6, 2018

Accepted: November 30, 2018

Статья поступила в редакцию 6 июля 2018 г.

Рекомендована в печать 30 ноября 2018 г. 